Article

\title{
A Sustainable Tourism Policy Research Review
}

\author{
Yi Guo ${ }^{1}{ }^{1}$, Jinbo Jiang ${ }^{1, *}$ and Shengchao $\mathrm{Li}^{2, *}$ \\ 1 School of Economics and Commerce, South China University of Technology, Guangzhou 510006, China; \\ ecguoyi@mail.scut.edu.cn \\ 2 School of Geography and Planning, Sun Yat-Sen University, Guangzhou 510275, China \\ * Correspondence: jbjiang@scut.edu.cn (J.J.); lishch3@mail2.sysu.edu.cn (S.L.)
}

Received: 10 May 2019; Accepted: 5 June 2019; Published: 6 June 2019

\begin{abstract}
After nearly three decades of development, sustainable tourism has been widely recognized in tourism policy practice and tourism research. In recent years, scholars have paid more and more attention to the topic of sustainable tourism policy research. The purpose of this paper is to analyze its development process and extract its research subject framework for reference in future research. This paper uses the systematic review method and the literature co-citation network analysis to classify the theme of sustainable tourism policy research into six categories, including: Sustainable tourism policy stakeholders, sustainable tourism policy implementation, sustainable tourism and climate policy, sustainable tourism indicators and planning, sustainable concepts in tourism policy, and the role of sustainable tourism policy. The development and implementation of sustainable tourism policies are an effective response to global environmental and sustainable development challenges. However, the current sustainable tourism policy is often economic-growth oriented, which has theoretical differences with sustainable development. At the same time, the research focus of scholars is on the impact of policies on the sustainable development of tourism, while the research on the formation process of policies and governance behaviors in the sustainable development of tourism is not enough.
\end{abstract}

Keywords: tourism; sustainable tourism policy; systematic review; co-citation network analysis

\section{Introduction}

In the late 1980s, sustainable development was proposed as an environmental management idea [1,2]. The World Tourism Organization (WTO) put forward the concept of Sustainable Tourism Development in 1993. In 1995, UNESCO, UNEP and WTO held the first World Conference on Sustainable in Spain. The Charter for Sustainable Tourism was adopted at the meeting, which marked that the sustainable development model has gradually occupied a dominant position in the tourism industry [1,3]. In 1993, the Journal of Sustainable Tourism, which was dedicated to sustainable tourism research, was established in the UK. This marks the important position of sustainable tourism research. Since then, sustainable development has gradually formed a value that is generally accepted by society. The connotation of sustainable tourism is constantly enriched, from the initial focus on environmental issues, to the issue of focusing on the overall balanced development of society, the environment and the economy [4]. Sustainable tourism is a development model in which tourism, resources and human living environment are unified, in which tourism is well coordinated with social economy, resources and environment. It is agreed that sustainable tourism emphasizes the long-term coordinated development of tourism activities with society, economy, resources and the environment. While meeting the needs of economic development, the negative impact of tourism activities will be reduced without compromising the natural and cultural resources on which tourism development depends. And through tourism activities to promote the efficient and sustainable use of resources. At 
the same time, sustainable tourism needs to coordinate and balance the relationship between different stakeholders in the process of tourism development. Sustainable tourism also emphasizes the fairness of intergenerational development opportunities.

Research on tourism policy began in 1975 when Mathews published an article entitled "International tourism and political science research" in the Annals of Tourism Research [5]. Subsequently, the number of studies on tourism policy research has increased annually. Hall and Jerkins began to study tourism policy in the early 1990s and proposed the conceptual framework of tourism policy research [6]. Sessa defined tourism policy as the actions determined and taken by various organizations to achieve specific tourism development goals [7], Hall and Jenkins defined tourism policy as the government's decision-making behavior in the tourism field [6], and Goeldner defined tourism policy as a set of guidelines that directly affect the long-term development and daily operation of a tourist destination [8]. The concept of tourism policy is ambiguous, and the scope of tourism policy research is quite broad [9], which makes it difficult to develop a unified research framework. There is no commonly accepted definition of tourism policy.

Sustainable tourism has always been a hot topic for scholars, and there are many studies on tourism policies. However, research on sustainable tourism policies is generally weak, and the review of sustainable tourism policy research is weaker. As an important part of sustainable tourism research, it is of great significance to analyze its development process. As an important part of sustainable tourism research, it is of great significance to analyze its development process. This paper uses bibliometrics to analyze the literature in the field of sustainable tourism policy research. The publication time, research cases, perspectives, topics and other contents of the literature were analyzed. It has identified the main research themes, directions and deficiencies of current sustainable tourism policy research, and hopes to provide suggestions for future research. The content of this paper is divided into four parts. The first part is the introduction, which introduces the overall structure of the article and the purpose of writing. The second part is the collection and analysis of research data. The third part is the bibliometric analysis of the collected literature co-citation network, aiming to find out the topics of sustainable tourism policy research. The fourth part is the summary of the whole paper.

\section{Method}

\subsection{Systematic Review}

To systematically evaluate and summarize the literature, the literature should be sorted and screened by appropriate methods. In this paper, a systematic review was used to systematically reorganize the literature on sustainable tourism policy research. The systematic review refers to the process of finding and analyzing documents related to a specific field of study [10]. The aim is to complete and elaborate on the existing literature related to research questions and provide a theoretical basis for scientific research. This approach overcomes the incompleteness and lack of objectivity of the narrative review. The conclusions are more authentic and reliable, due to a more comprehensive literature collection. There are four main stages of systematic review:

- Define research questions and choose analysis methods.

- Search for relevant data from studies that match certain criteria.

- Extract and evaluate relevant data.

- Use statistical methods to analyze and combine data to provide a general analysis of all data.

This paper adopts the analytical framework of a systematic review. By using bibliometric methods and complex network theory, this paper systematically analyses the literature on sustainable tourism policy research. There are four main steps:

- Clarifying the purpose of this study, which is to review research progress on sustainable tourism policy research using a systematic review as the main research method.

- Collecting literature on sustainable tourism policy research. 
- Extracting and evaluating the collected literature.

- Using a complex network theory to build a literature co-citation network and determine the subjects and direction of sustainable tourism policy research.

\subsection{Literature Co-Citation Network Analysis}

The literature co-citation network analysis is based on quantitative information from databases (such as Web of Science) to identify influential papers and use the collective judgement of scholars to conduct a literature analysis. Literature co-citation is a measure of the similarity between articles, authors, or journals [11]. If two papers appear in the references of the same paper, they are likely to have similar characteristics. If they appear together in many references, the two texts have a strong connection. We build the literature co-citation network based on the collected research studies and their references and determine the research topics of sustainable tourism policy research.

We use the Louvain algorithm to find group relationships among the cited literature. Using the algorithm of Blondel et al. [12], clustering analysis is conducted on the literature network and the network is divided into several communities based on modularity $Q$. A scalar value between -1 and 1 is used to measure the correlation strength between the modules and within the module, and the quality of the module partition is defined as follows:

$$
Q=\frac{1}{2 m} \sum_{i, j}\left[\left(w_{i, j}-\frac{A_{i} A_{j}}{2 m}\right) \delta\left(c_{i}, c_{j}\right)\right] .
$$

In formula (1), $w_{i, j}$ represents the weight of the line segment between node $i$ and node $j$, and $m$ is the weighted sum of all segments in the network. In this article, the node is a document, the line is a citation relationship, and the weight of the line is the number of citations. In the unauthorized network, the value of the reference relationship between the two articles is 1 ; otherwise, it is $0 . A_{i}=\sum_{j} w_{i, j}$ on behalf of all the nodes $i$ connect the line weight sum. $c_{i}$ represents the community where node $i$ is located. When node $i$ and node $j$ are in the same community, $\delta\left(c_{i}, c_{j}\right)$ is 1 ; otherwise, the value is 0 .

The partition community is calculated by a two-step iterative algorithm. The first step is to take each node as a community, such that the number of communities is equal to the number of nodes. We merge node $i$ into the community of adjacent node $\mathrm{j}$ and calculate the module degree gain. We then add $i$ to all other adjacent communities and calculate the respective $\Delta Q$. If the $\Delta Q$ number is positive, then node $i$ is merged into the community with the maximum value of the node $\Delta Q$; otherwise, node $i$ remains in the original community. We repeat the above process to compute all nodes until we can no longer optimize, at which point the first step ends. The formula for the modularity gain is as follows [12,13]:

$$
\begin{gathered}
\Delta Q=\left[\frac{\sum C_{i n}+A_{i, i n}}{2 m}-\left(\frac{\sum t o t+A_{i}}{2 m}\right)^{2}\right]-\left[\frac{\sum C_{i n}}{2 m}-\left(\frac{\sum t o t}{2 m}\right)-\left(\frac{A_{i}}{2 m}\right)^{2}\right], \\
m=\frac{1}{2} \sum_{i, j} w_{i, j} .
\end{gathered}
$$

In Formula (2), the $\sum C_{i n}$ represents the sum of all of the internal line weight in the group, $\sum$ tot represents all connections to any node in the group $C$ segment of the weighted summation, $A_{i}$ represents the summation of all weighted line connection nodes, $A_{i, i n}$ is the connection of node $i$ and community $C$ line weighting the sum of all other nodes, and $m$ is the weighted sum of all segments in the network.

The second step is to build a new network based on the results of the first step. After the second step is completed, the first step is applied to the network built in step 2 until the network no longer changes. The network module is the largest. 
By combining the clusters in the original literature network, the hidden relationships and structures in the network are revealed, and the network can be analyzed and interpreted through these structures and relationships.

Finally, based on the data network analysis results, the network visualization of data using Pajek software is presented.

\subsection{Data Collection}

First, the keywords are used to search the literature in the selected database. This study selected academic research papers from three databases (SCI - EXPANDED, SSCI, A\&HCI) in the Web of Science's core collection. The search was conducted on April 20, 2019. The search term is "sustainable tourism policy". We collected a total of 515 results (Table 1).

Table 1. Searching information record.

\begin{tabular}{cc}
\hline Database & $\begin{array}{c}\text { Science Citation Index Expanded (SCI-EXPANDED)-1999-present } \\
\text { Social Sciences Citation Index (SSCI)-2002-present } \\
\text { Arts and Humanities Citation Index (A\&HCI)_-2002-present }\end{array}$ \\
\hline Key Words & sustainable tourism policy \\
Search Condition & Topic \\
Year & 1986-present \\
Research Areas & All \\
Result & 515 \\
\hline
\end{tabular}

The result shows that the 515 articles came from 167 journals. Journals containing more than five papers are shown below (Table 2).

Table 2. Sources of the literature.

\begin{tabular}{ccc}
\hline Source Journals & Records & Percentage \\
\hline JOURNAL OF SUSTAINABLE TOURISM & 75 & $14.56 \%$ \\
SUSTAINABILITY & 45 & $8.74 \%$ \\
CURRENT ISSUES IN TOURISM & 22 & $4.27 \%$ \\
TOURISM MANAGEMENT & 19 & $3.69 \%$ \\
JOURNAL OF CLEANER PRODUCTION & 16 & $3.11 \%$ \\
TOURISM MANAGEMENT PERSPECTIVES & 14 & $2.72 \%$ \\
OCEAN AND COASTAL MANAGEMENT & 11 & $2.14 \%$ \\
ANNALS OF TOURISM RESEARCH & 10 & $1.94 \%$ \\
TOURISM GEOGRAPHIES & 10 & $1.94 \%$ \\
ECOLOGICAL INDICATORS & 9 & $1.75 \%$ \\
JOURNAL OF COASTAL RESEARCH & 8 & $1.55 \%$ \\
LAND USE POLICY & 8 & $1.55 \%$ \\
MARINE POLICY & 8 & $1.55 \%$ \\
ECOLOGICAL ECONOMICS & 8 & $1.55 \%$ \\
JOURNAL OF DESTINATION MARKETING AND MANAGEMENT & 7 & $1.36 \%$ \\
JOURNAL OF TRAVEL RESEARCH & 7 & $1.36 \%$ \\
WNTERNATIONAL JOURNAL OF SUSTAINABLE DEVELOPMENT AND & 7 & $1.36 \%$ \\
\hline
\end{tabular}

The number of papers published each year has grown rapidly. The number of studies in the last five years accounted for more than half of the total. As shown in Figure 1, the largest number was in 2018, with 78 articles, followed by 72 in 2017 and 59 in 2016 (Figure 1). 


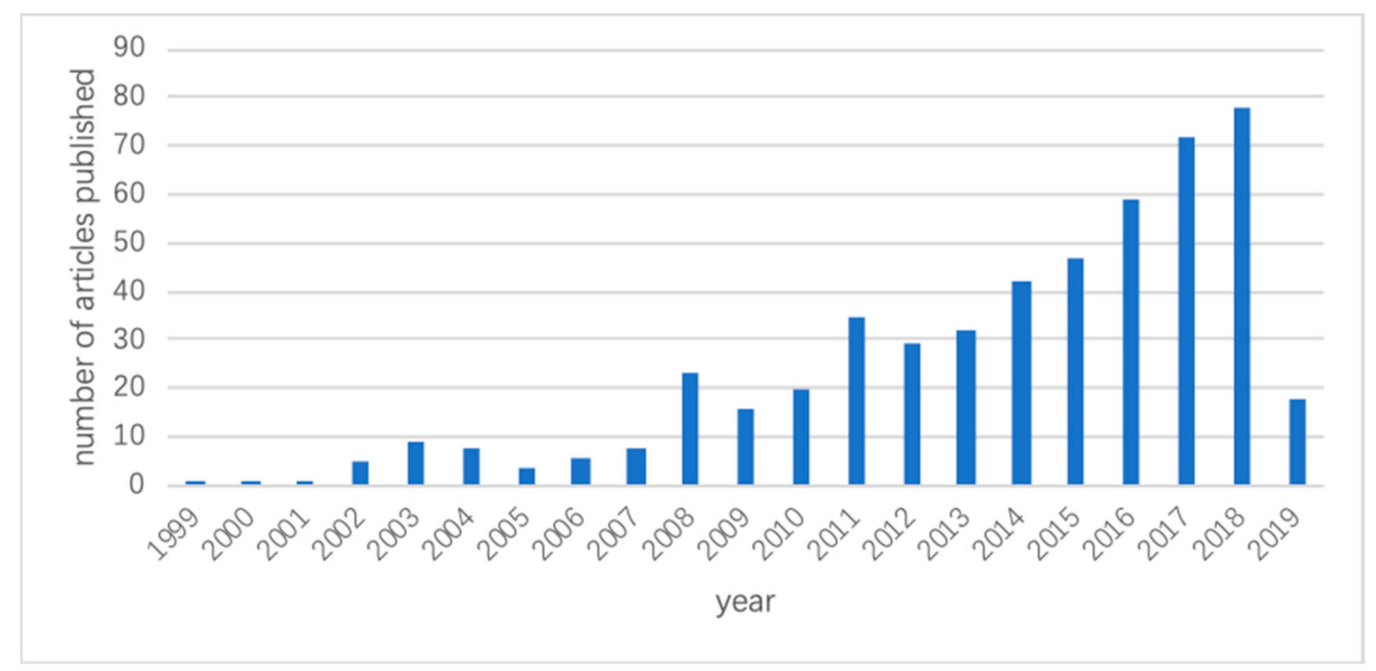

Figure 1. Time distribution of articles.

\subsection{Data Analyses}

First, we read the abstracts of 515 papers and deleted the literature that did not involve sustainable tourism policy and theoretical arguments. In this way, 49 papers were selected. Compared with other literature using similar methods, we confirm that this is a reasonable amount [14-17]. Using EXCEL, information was identified on the selected 49 papers, including the title, author, journal, and year of publication. Then, the literature was analysed, and the study cases, research methods, research perspectives and scale of research were summarized [18,19].

\subsubsection{Case Distribution}

At the intercontinental level, 20 of the 49 papers focused on European sustainable tourism policy (40.82\%), followed by Asia (12), Oceania (6), North America (5), Africa (2), and Latin America (1). Only two papers presented research on a global scope. Seven papers had no study case. Overall, there were few studies involving cross-regional and multi-regional approaches (Table 3).

Table 3. Statistics of study cases.

\begin{tabular}{ccc}
\hline Continent & Number & Percentage \\
\hline Europe & 20 & $40.82 \%$ \\
Asia & 12 & $24.49 \%$ \\
Oceania & 6 & $12.24 \%$ \\
North America & 5 & $10.20 \%$ \\
Africa & 2 & $4.08 \%$ \\
South America & 1 & $2.04 \%$ \\
global & 2 & $4.08 \%$ \\
No case & 7 & $14.29 \%$ \\
\hline
\end{tabular}

At the country level, there are three cases in China, Turkey, Spain, Norway and Australia respectively, two cases in Britain, Italy, Romania, Pacific island countries and Canada respectively, and one case in Vietnam and Singapore respectively (Table 3).

\subsubsection{Methods}

By analyzing the research methods used in the literature, we find that qualitative methods are used more in the field of sustainable tourism policy research. Common methods include SWOT analysis, complex systems, structural equation models, grounded theory, and indexing systems. 


\subsubsection{Scales}

With regard to the scale of the study, sustainable tourism policy research can be divided into four scales: (1) The macro-scale, including the global, international areas and country scale (26 articles, accounting for $50.06 \%$ ); (2) the middle scale, including the domestic areas and city scale (16 articles, accounting for $32.65 \%$ ); (3) the micro-scale, including the scenic area scale ( 3 articles, accounting for $6.12 \%$ ); and (4) other scales, including studies with no clear scale (accounting for $12.24 \%$ ). As shown in Table 4, most papers focus on the macro level (Table 4).

Table 4. Statistics of study scales.

\begin{tabular}{cccc}
\hline \multicolumn{2}{c}{ Study Scale } & Number & Percentage \\
\hline \multirow{2}{*}{ Macro Scale } & Global & 2 & $4.08 \%$ \\
& International Area & 1 & $2.04 \%$ \\
& Country & 23 & $46.94 \%$ \\
Mesoscale Scale & Domestic Area & 9 & $18.37 \%$ \\
Microscopic Scale & City & 7 & $14.29 \%$ \\
Other Scales & Scenic Area & 3 & $6.12 \%$ \\
\hline
\end{tabular}

\section{Results}

\subsection{The Co-Citation Network}

The analysis of the co-citation of the literature helps us to understand the research themes of sustainable tourism policy studies. In this paper, a total of 2524 basic and reference articles are selected as the database. Through the above calculation method, 133 articles with a frequency greater than three are selected to build the literature reference network (Figure 2). The circles in the figure represent the articles, and each article is marked with a number in the circle. The size of the circle indicates how often the article was cited. Lines represent the citation relationship between articles. One or several articles in each community that are cited most often and are located at the center of the network are the core articles.

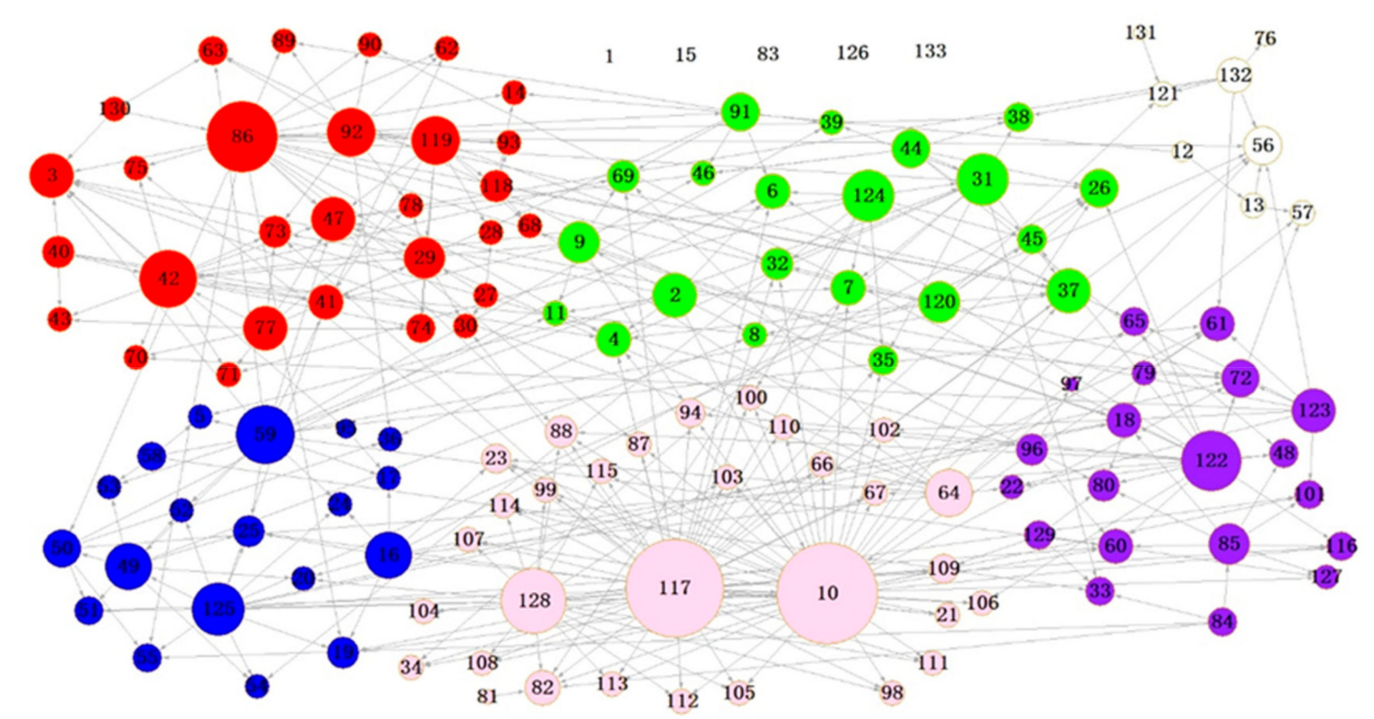

Figure 2. Sustainable tourism policy research literature reference network.

Six literature co-citation networks were identified, and the relationship between these six communities was obtained (Figure 3). The circle in the figure represents the communities, and each community is marked with a number in the circle. The lines represented cite the relationship between communities. The thickness of the lines represents the strength of the community connection. 


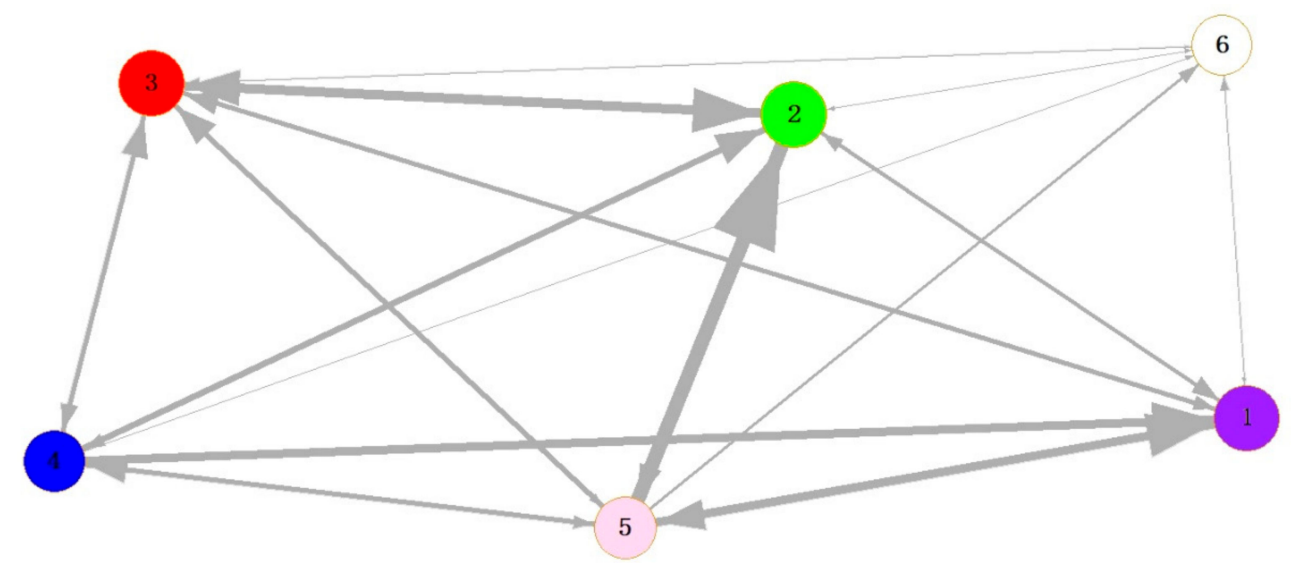

Figure 3. Sustainable tourism policy research literature community relations.

The study of these six clusters helps to reveal the main research directions and themes of sustainable tourism policy research. The largest among the six communities was community No.5, which contains 31 articles. It can be seen from the community diagram that community No.5 is closely linked to community No.1 and No.2. The second-largest community is No.3, which contains 29 articles. It is closely linked to community No.2. Community No.2 contains 21 articles. It is closely linked to community No.3 and No.5. Community No.1 contains 20 articles. It is closely linked to community No.4 and No.5. Community No.4 contains 19 articles. It is closely linked to community No.1 and No.2. Community No.6 contains 12 articles. Next, the six literature communities were analyzed separately, and the research themes and characteristics of each community were summarized (Table 5).

Table 5. Six literature communities and themes.

\begin{tabular}{|c|c|c|c|}
\hline $\begin{array}{l}\text { Community } \\
\text { Number }\end{array}$ & $\begin{array}{l}\text { Number of } \\
\text { Articles }\end{array}$ & Themes & Key Articles \\
\hline 1 & 20 & $\begin{array}{l}\text { Sustainable tourism policy } \\
\text { stakeholders }\end{array}$ & Simao and Partidario 2012 [20], Solstrand 2013 [21] \\
\hline 2 & 21 & $\begin{array}{l}\text { Sustainable tourism policy } \\
\text { implementation }\end{array}$ & Bramwell 2011 [22], Stumpf and Swanger 2015 [23] \\
\hline 3 & 29 & $\begin{array}{l}\text { Sustainable tourism and } \\
\text { climate policy }\end{array}$ & Gossling et al. 2012 [24], Moyle et al. 2014 [25] \\
\hline 4 & 19 & $\begin{array}{l}\text { Sustainable tourism } \\
\text { indicators and planning }\end{array}$ & $\begin{array}{l}\text { Fernandez-Tabales et al. } 2017 \text { [26], Tanguay, Rajaonson } \\
\text { and Therrien } 2013 \text { [27], Castellani and Sala } 2010 \text { [3] }\end{array}$ \\
\hline 5 & 31 & $\begin{array}{l}\text { Sustainable concepts in } \\
\text { tourism policy }\end{array}$ & $\begin{array}{c}\text { Saarinen 2014, } 2006 \text { [28,29], Fodness } 2017 \text { [30], Vellecco } \\
\text { and Mancino } 2010 \text { [31] }\end{array}$ \\
\hline 6 & 8 & $\begin{array}{l}\text { The role of sustainable } \\
\text { tourism policy }\end{array}$ & Butler 1999 [32], Xu and Sofield 2016 [33] \\
\hline
\end{tabular}

\subsection{Themes}

\subsubsection{Sustainable Concept in Tourism Policy}

Community 5 includes 31 articles on the sustainability concept in sustainable tourism policy. In recent years, tourism research has been exploring the concept of sustainable development. During this period, sustainable development has become an important policy framework for tourism to guide its planning and development thinking. Sustainability has also become an important research area in academics. However, despite the urgent need to integrate sustainability into tourism, scholars still lack important progress in the study of the relationship between sustainability and personal interests. In this case, the basic theories and concepts of tourism sustainability need to be re-established in a policy framework and practice for achieving sustainability [29]. Many countries have begun to focus on sustainable development in their policies, and tourism has begun to shift to sustainable development. Although sustainability is an important part of tourism policy, the concept of tourism sustainability is 
not clear, and policies that focus on economic growth still play a leading role. $\mathrm{Xu}$ proposes to combine a proactive approach to sustainability with future environmental issues to develop sustainable tourism policies that enable tourism to participate constructively in the transition of the country to a sustainable society [33]. Vellecco surveyed the environmental awareness of Italian tourism entrepreneurs and other stakeholders, validated their support for environmental policies and sustainable tourism policies, and assessed local communities' commitment to environmental protection. The results show that sustainable tourism policies are difficult to implement, due to the lack of shared responsibility [31].

Sustainability has become an important policy issue for the tourism industry, which has caused more and more discussion and criticism. People increasingly need to understand the essence of the growth limit. Scholars have conducted a critical discussion of the relationship between sustainable tourism and sustainable development, and analyzed how to approach and evaluate these limitations in a localized discussion. It was found that the understanding of tourism sustainability has three different traditions of resources, activities and communities, representing different aspects and elements of the concept of sustainability [28]. Over time, the development of tourist destinations is prone to significant spillover effects. Market tools may not help correct these spillover effects until the environment has significantly deteriorated. Therefore, sustainable tourism policies need to consider not only the balance and coordination between sectors, but also the potential impact of various development strategies that are not directly related to tourism [34]. The imbalanced performance of sustainable tourism policies and planning is becoming more and more obvious. The traditional tourism problem solving paradigms and methods cannot effectively solve all the problems that arise in sustainable tourism. It is meaningful to understand and solve the sustainable development of tourism from the three perspectives of the Cynefin Framework, Complexity Science and Wicked Problems [30]. Tourism development and system theory are closely related, and the system structure may affect the development of sustainable tourism. Rapid growth in tourism can have disastrous consequences that could eventually lead to a decline in tourism. Therefore, the focus of sustainable tourism policy must shift from economic growth to growth without undermining tourism carrying capacity [35].

Sustainable tourism can be a paradox. On the one hand, the concept of sustainable tourism is recognized and widely disseminated by industry, government, academics and policy actors. This shows that sustainable tourism is successful. On the other hand, the current development of tourism objectively has an increasing impact on the environment, indicating that sustainable tourism is a failure. The likely reason is that policymakers are reluctant to acknowledge the failure of sustainable tourism policies, and in the past policy learning was only at the level of policy tools and policy concepts. To promote sustainable tourism development, we need to change the dominant paradigm of sustainable tourism policy [1]. If the systemic and institutional impacts are not addressed, the likelihood that tourism activities and behavior will be locked into an unsustainable social technology supply system will increase significantly. If one wants to develop appropriate tourism behaviors, then changing the social technology system is crucial $[24,36]$.

\subsubsection{Sustainable Tourism Policy Implementation}

Community 2 includes 21 articles on the implementation of sustainable tourism policies. The case of these documents covers Germany, China, Malta, Turkey, the United Kingdom, the Pacific island countries, Denmark, Cambodia, Maldives and other regions. The research scale is mostly a country, and the research perspective is mainly from the government perspective.

The focus of implementing sustainable tourism development is not only to change people's ideas and understanding, but more importantly, to implement sustainable tourism policies effectively. There are many obstacles to the implementation of sustainable tourism policies. The difficulty of successfully implementing policies is not technical, but involves political, cultural, economic, social and human psychological changes. Sustainable tourism policy is complex because it inevitably interacts with other policies. Policymakers must not only raise awareness of their policies, but also act on policies to achieve sustainable tourism goals [2]. A systematic analysis of the interrelationship between tourism and 
politics from multiple levels reveals that tourism helps to change the power arrangements and values of the destination area. In turn, tourism patterns and processes are also responses to different values [37]. National governance also has a major impact on the sustainability of tourism destination management. This governance faces major obstacles because it involves many policy areas, many of which are developed in other policy areas and have difficulty affecting private sector decision-making. And the relevant actors are diverse and have different interests and priorities. Case studies from Germany, China, Malta, Turkey and the United Kingdom have also shown that political economic analysis can reveal how state interventions affect tourism and sustainability in tourism destinations [22]. An analysis of the Danish coastal tourism development process shows that policymakers have not treated sustainable tourism development as a holistic concept. Policies over-emphasize economic benefits and largely lack long-term plans. Government leadership is weak in the transition to sustainable tourism development [38].

The public is concerned about environmental degradation, human rights issues, the links between political and economic elites, and the huge economic gap associated with tourism. Sustainable tourism research needs to recognize the key role of the state in guiding tourism development and consider how the state balances conflicts of interest among multiple stakeholders. Power and political issues are critical to the sustainable development of tourism [39]. There is still a gap between policy development and implementation. And different stakeholder groups have different understandings of sustainable tourism, and these differences in perception are related to their own interests [40]. Some countries have developed tourism policies at the national level that target sustainable tourism development. Government officials are more concerned about increasing tourism revenues, infrastructure construction and investment, tourism promotion and marketing, tourism diversification, tourism development, and tax laws and regulations. These concerns are economically driven and growth oriented. There is an inconsistency between the priorities of officials and the goals of sustainable tourism policies in national tourism strategies [41]. Geographical differences need to be considered in sustainable tourism policies, including models of regional economic development, institutional and policy environments, ideological value systems, and their associated power relationships [42].

The relatively sound policy and regulatory framework are both critical to planning sustainable tourism development. Despite the enthusiasm of governments for sustainable tourism, existing policy and regulatory frameworks are often filled with conflicting goals. Moreover, often the legal provisions are ambiguous, many organizational responsibilities are repeated, and the definition of responsibility is not clear. To solve these problems, governments at all levels should have a stronger political will to overcome the general mentality of short-term economic growth and overcome the deep-rooted approach of pursuing sectoral interests. In addition, more rational and effective institutional arrangements are needed to clearly define the functions and responsibilities of governments at all levels [43]. The third world tourism industry is threatened by many problems that have plagued the development of other export-oriented industries in the post-war period. These problems include excessive dependence on foreign resources leading to loss of local control over resources; large loss of tourism revenues to overseas; lack of convergence between tourism enclaves and domestic economic sectors, low multiplier and diffusion effects; socioeconomic and spatial polarization The strengthening of the neocolonial model led to the destruction of the non-renewable resources environment; the uneven distribution of costs and benefits of tourism, and the loss of cultural identity and social control, resulting in the alienation of local residents of the host country community. Therefore, sustainable tourism policies should not only focus on increasing the number of tourists or income, but also better serve the tourism industry to serve the broader development goals of local communities, regions and countries [44]. Tourism involvement-conformance theory can help policymakers better coordinate the relationship between internal and external forces in the evolving tourism industry. It also promotes an understanding of culture, participation, power and consistency in tourism research [23]. In addition, mutual policy learning between countries and regions can increase competitiveness and sustainability as a tourist destination $[45,46]$. 


\subsubsection{Sustainable Tourism Policy Stakeholders}

Community 1 includes 20 articles on the topics of sustainable tourism policy stakeholders. Cases of these documents are related to Portugal, Norway, Canada, the United States, Vietnam, the United Kingdom, Mexico, Egypt and other regions. The research scale is mostly a country or region.

Tourism depends on the environmental, material and socio-cultural resources of the tourist destination. Therefore, to achieve greater tourism sustainability, stakeholders need to participate in sustainable tourism policy development and implementation processes, as well as long-term strategic planning [24]. The controversy over sustainable tourism development in many regions is influenced by the complex power relationships among multi-stakeholders [47]. The interpretation of the concept of sustainability in current sustainable tourism policies is vague. There is a general lack of public participation and discussion of sustainability in existing programs, making planning difficult to implement effectively [20]. To develop a better sustainable tourism policy, we need to actively communicate with stakeholders. In the process of formulating and implementing sustainable tourism policies, we must not only pay attention to tourism economic income, but also prioritize the minimization of conflicts among multiple stakeholders [21]. There are differences in sustainable tourism development goals and development paths under different conditions. An oversimplified and inflexible sustainable tourism paradigm cannot explain specific sustainable tourism development issues. For example, who leads the development of sustainable tourism policies, how communities and local governments participate in sustainable tourism, and how to coordinate the relationships of different stakeholders $[48,49]$. The public sector plays an important role in promoting "bottom-up" governance [50]. Lack of communication between different stakeholder groups makes it difficult to develop a unified policy. Therefore, a sustainable development network is needed to coordinate the interactions between multiple stakeholders with different objectives, different interests and powers. The interlinkages of different stakeholders on sustainable development issues can improve the sustainable development of urban tourism destinations. However, it is unclear which organization will play a leading role in increasing communication and cooperation between different stakeholders [51].

\subsubsection{Sustainable Tourism and Climate Policy}

Community 3 includes 29 articles on climate, environmental policy and sustainable tourism policies. These case locations include Australia, Norway, Spain, Canada, Pacific Island Countries, and Italy.

Tourism is a key factor affecting climate change, but it is unclear how tourism actually affects climate change in practice. Scholars analyzed the complex challenges that climate change poses to tourism and how tourism policies fit into these challenges. The results show that the government actively develops and participates in climate change programs, develops more green tourism products, and strengthens dialogue around climate change to achieve tourism sustainability [52]. After decades of development, the concept of sustainable tourism has been deeply embedded in government policies. The concept of sustainable tourism has also shifted from initially focusing on the relationship between nature and society to shifting more to climate change, social responsibility and development model transformation [25]. Coastal tourism destinations show significant vulnerability to climate change. The study found that in addition to the physical characteristics of destinations and the direct impact of climate change, public policy is a key determinant of destination vulnerability. Policy framework inherent weaknesses, lack of integration between sustainable tourism policy and climate change policies, lack of coordination between the public administration have led to the vulnerability of destination [53].

The relationship between tourism and climate change is mutual. The consistency of sustainable tourism policies and climate change policies is of great significance for the implementation of the two policies. But there are also many difficulties in coordinating sustainable tourism policies and climate change policies [54]. Sustainable tourism policies and climate policies evolve in different ways. Because they are all subject to their own values, stakeholders and even jurisdiction. This limits the mutual 
cooperation between the two policy areas in establishing common goals and designing common policy instruments [55]. The current participation of tourism in climate change is expanding, which is not necessarily conducive to the sustainable development of tourism [56]. There are also opposing views that addressing climate change is a prerequisite for sustainable development and is therefore closely related to the promotion of sustainable tourism policies. In the past, the concept of sustainable tourism was almost entirely focused on the scale of tourism destinations, and emphasized the need to give due consideration to the environmental and social impacts of different stages of development of tourism. At the same time, tourism cannot ignore the long-term nature of sustainable development, although it is more challenging for planners and policymakers. Only in a longer time frame can we consider the various social and economic conditions that may be possible in the development of international tourism and climate change [57].

\subsubsection{Sustainable Tourism Indicators and Planning}

Community 4 includes 19 articles on the subject of sustainable tourism policy indicators and planning. Cases of these documents are located in Spain, the European Union, New Zealand, Turkey, Romania and other regions. There are significant uncertainties in the formulation and implementation of sustainable tourism policies, especially in the context of current globalization trends that have affected local government decisions and the weak economic growth of major Western economies. Therefore, it is necessary to evaluate indicators to compare the strengths and weaknesses of policies, and thus guide the government to better develop and implement sustainable tourism policies. In general, comprehensive sustainability indicators are developed during long-term practice. Many scholars have constructed a variety of indicator systems through various methods.

Castellani et al., considering the long-term and short-term benefits of sustainable tourism policies, constructed an indicator system for evaluating sustainable tourism policies at tourism destinations [3]. Tanguay et al., based on a case in Quebec, developed 20 sustainable tourism indicators to guide the development of sustainable tourism policies [27]. Fernández-Tabales et al. constructed an evaluation system consisting of 43 indicators in five aspects to evaluate the effectiveness of sustainable tourism policy implementation. The example of Andalusia, Spain, was used to verify the effectiveness of the indicator system [26] Blancas et al. used the Andalucian region of Spain as an example to construct an evaluation system with three indicators to describe the sustainable tourism development status of tourism destinations and to build sustainable tourism development goals, to help policymakers better formulate and Implement policies [58]. Choi et al. used the Delphi method to construct an indicator system for measuring the development of community tourism under the framework of sustainable development. The indicator system consists of 125 indicators in six dimensions [59]. Ko introduced Barometer of tourism sustainability (BTS) and AMOEBA of tourism sustainability indicators (ATSI) to assess tourism sustainability in 12 case sites [60]. Miller surveyed tourism researchers' views on sustainable tourism indicators through the Delphi method. The results show that although it is generally considered necessary to pay attention to the long-term development of tourism, there is no consensus on what policies should be adopted. There are also differences as to who should be responsible for mitigating the environmental impact of tourism and the fairness of sustainable tourism policies [61]. Based on the recommendations of the World Tourism Organization, Blancas et al. constructed an indicator system for assessing the sustainability of coastal tourism destinations, which can objectively compare destinations and rank them. The results can be used as a guide for tourism planning [62].

\subsubsection{The Role of Sustainable Tourism Policy}

Community 6 includes eight articles on the subject of sustainable tourism policy evaluation. Although tourism scholars and practitioners have paid great attention to sustainable tourism development in recent years, in tourism research, they have never been able to link the concept of sustainable development with their paradigm theory. Therefore, few people question whether 
the concept of sustainable development applies to the specific situation of tourism. Reviewing the development process of sustainable tourism theory, it is not difficult to find that although sustainable tourism should logically reflect the principle of sustainable development, there are significant differences between the two concepts. The principle of sustainable development cannot be transferred to the tourism industry as a specific economic and social activity. This is not to say that many of the principles of sustainable tourism are ineffective. On the contrary, these sustainable tourism policies encourage people to pay attention to the integrity of tourism and the environment while developing tourism, and encourage the development of more environmentally friendly forms of tourism that best meet the social and economic development goals of the destination [63]. Sustainable tourism is the future direction of development, and people are increasingly interested in this concept. But this does not ensure the achievement of sustainable tourism development goals. In the absence of accurate and reliable indicators and monitoring, sustainable development will take years to evaluate. Only after comparing its development methods and effects can it be compared with the environmental conditions at the time of its establishment. Considering that the term "sustainable development" did not enter the dictionary until 1987, it is too early to say whether any sustainable tourism policy developed, since then is truly sustainable $[32,64]$. The biggest challenge for sustainable tourism is how to properly respond to changing environmental conditions and characteristics of the times. In the current situation, any policy aimed at influencing tourism must take sustainability as an important factor [4].

Incorporating sustainable tourism into public policy is challenging for most countries. In most countries, sustainable tourism policies are far from integrated, and policy integration is a horizontal integration of national policies, bottom-up integration prepared by institutional reforms, public participation, and active use of municipal planning systems [65]. Internationally accepted recommendations for sustainable tourism development do not necessarily apply to every country, and may lack the necessary coordination when applied in some countries. Tourism stakeholders have largely supported measures to improve coordination, but there are differences on what to do [66]. In addition, the labor and employment issues are related to the ability of tourism service delivery and service quality, which in turn affects the sustainable development of tourism, and is a prerequisite for the sustainable growth of tourism. There is a general lack of attention to employment or labor in current sustainable tourism policies [67].

\section{Discussion and Conclusions}

The term sustainable tourism emerged in the late 1980s. After nearly three decades of development, it has been widely disseminated and recognized in tourism policy practice and tourism research [1]. The study of sustainable tourism policy is to analyze the process and progress of the development of sustainable tourism policies. Summarize the evolution of sustainable tourism policies and the interaction between them, explain the meaning and role of sustainable tourism policies and the ideological principles behind them. Evaluate, revise, and improve sustainable tourism policies based on social practice, and guide the implementation of sustainable tourism policies.

In recent years, the study of sustainable tourism policy has attracted more and more scholars' attention, and the number of researches has been increasing. At the same time, it has the characteristics of diverse research contents and methods, and the wide distribution of research cases. From the publication time of the literature, nearly half of all the collected documents were published in the last five years. It can be seen that scholars have paid more attention to the topic of sustainable tourism policy research in recent years. From the perspective of the research case, Europe has always been an area where scholars have studied the most because of the developed tourism economy. With the economic growth of developing countries and the development of tourism, research in developing countries and regions, such as Asia and Africa have gradually increased. As global climate issues become more prominent, research in climate-sensitive areas, such as the Caribbean and small island states of the Pacific has increased. There are fewer cross-regional and multi-regional studies. Research methods in sustainable tourism policy are diverse, drawing on and integrating methods from many other 
disciplines, such as management, political science, economics, geography, and sociology. This paper divides the theme of sustainable tourism policy research into six categories, including: Sustainable tourism policy stakeholders, Sustainable tourism policy implementation, Sustainable tourism and climate policy, Sustainable tourism indicators and planning, sustainable concepts in tourism policy, The role of sustainable tourism policy. In general, the literature on sustainable tourism policy has paid less attention to social issues, as compared with environmental issues.

Compared with the market, the role of policies in the sustainable development of tourism is more obvious. This makes scholars realize that the use of political means for environmental and resource protection will undoubtedly have higher performance. Therefore, the relationship between sustainable tourism policy and resource environment has become a research hotspot. However, the current research focus of scholars is on the impact of policies and governance behaviors on sustainable tourism development. There is insufficient attention to the formation of policies and governance behaviors in the process of sustainable tourism development.

The importance of stakeholders in sustainable tourism policies is often seen as a commonplace topic. However, it is often included in the description of the policy and is considered self-evident and rarely receives further attention. While stakeholders are often mentioned as important, there are few detailed studies on how to identify, participate, and collaborate with stakeholders. In addition, descriptions of tourism stakeholders include different groups, but the most frequently included groups are large tourism companies and government tourism agencies. There are also studies that focus on how these stakeholders can participate more effectively in the development and implementation of sustainable tourism policies. Different stakeholders have different views on sustainable tourism policies, and differences in these perceptions may make policies difficult to implement.

There is a theoretical divergence between the concept of sustainable tourism development and sustainable development. Although sustainable tourism should logically reflect the principles of sustainable development, there are significant differences between the two concepts. In particular, although sustainable tourism development is ostensibly a comprehensive, fair and future-oriented development strategy, it is largely product-centric. In other words, although it encompasses the goal of environmental sustainability, sustainable tourism does not seem to be in line with the path of sustainable development. The inherent dependence on capital and consumption in tourism is not easy to meet the principles of endogenous and alternative development. Therefore, the principle of sustainable development cannot be transferred to the tourism industry as a specific economic and social activity. Real tourism sustainability is almost impossible to achieve. This is not to say that tourism does not play an important role in sustainable development. In fact, the growth of tourism has proven to be an effective tool for many countries to achieve sustainable economic growth and corresponding socio-economic development. The development and implementation of sustainable tourism policies are an effective response to global environmental and sustainable development challenges.

The purpose of this paper is to analyze the development process of sustainable tourism policy, and extract the research theme framework for reference in future research. Not all databases are included in this article, and future research can further refine this framework by supplementing the literature in other databases.

Author Contributions: Conceptualization, Y.G. and S.L.; Data curation, Y.G. and S.L.; Formal analysis, Y.G. and S.L.; Funding acquisition, Y.G. and J.J.; Investigation, Y.G. and S.L.; Methodology, Y.G. and S.L.; Project administration, Y.G. and S.L.; Resources, Y.G. and S.L.; Software, Yi Guo and S.L.; Supervision, Yi Guo and S.L.; Validation, Y.G. and S.L.; Visualization, Y.G. and S.L.; Writing一original draft, Y.G. and S.L.; Writing一review \& editing, Y.G. and S.L.

Funding: This research was funded by The National Natural Science Foundation of China (to Jinbo Jiang) (No. 41671150), and 2018 10,000 Tourism Talents Program of the Ministry of Culture and Tourism of China (to Yi Guo) (No. WMYC20181-026).

Conflicts of Interest: The authors declare no conflict of interest. 


\section{References}

1. Hall, C.M. Policy learning and policy failure in sustainable tourism governance: From first- and second-order to third-order change? J. Sustain. Tour. 2011, 19, 649-671. [CrossRef]

2. Dodds, R.; Butler, R. Barriers to implementing Sustainable Tourism Policy in Mass Tourism Destinations. Tourismos 2010, 5, 35-53.

3. Castellani, V.; Sala, S. Sustainable performance index for tourism policy development. Tour. Manag. 2010, 31, 871-880. [CrossRef]

4. Torres-Delgado, A.; López Palomeque, F. The growth and spread of the concept of sustainable tourism: The contribution of institutional initiatives to tourism policy. Tour. Manag. Perspect. 2012, 4, 1-10. [CrossRef]

5. Mathews, H.G. International Tourism and Political Science Research. Ann. Tour. Res. 1975, 2, $195-203$. [CrossRef]

6. Hall, C.M.; Jenkins, J. Tourism and Public Policy; Routledge: London, UK, 1995; pp. 523-540.

7. Sessa, A. The Tourism Policy. Ann. Tour. Res. 1976, 3, 234-247. [CrossRef]

8. Goeldner, C.R.; Ritchie, J.R.B.; Goeldner, C.R.; Ritchie, J.R.B. Tourism: Principles, Practices, Philosophies; John Wiley \& Sons: Hoboken, NJ, USA, 2012; Volume 14, p. 414.

9. Soshiroda, A. Inbound tourism policies in Japan from 1859 to 2003. Ann. Tour. Res. 2005, 32, 1100-1120. [CrossRef]

10. Petticrew, M.; Roberts, H. Systematic Reviews in the Social Sciences: A Practical Guide; Blackwell Publishing: Malden, MA, USA, 2008.

11. Zupic, I.; Čater, T. Bibliometric methods in management and organization. Organ. Res. Methods 2015, 18, 429-472. [CrossRef]

12. Blondel, V.D.; Guillaume, J.L.; Lambiotte, R.; Lefebvre, E. Fast Unfolding of Communities in Large Networks. J. Stat. Mech. 2008, 2008, 155-168. [CrossRef]

13. Blondel, V.D. A Counterexample to a Simultaneous Stabilization Condition for Systems with Identical Unstable Poles and Zeros. Syst. Control Lett. 1991, 17, 339-341. [CrossRef]

14. Kinkeldey, C.; MacEachren, A.M.; Schiewe, J. How to Assess Visual Communication of Uncertainty? A Systematic Review of Geospatial Uncertainty Visualisation User Studies. Cartogr. J. 2014, 51, 372-386. [CrossRef]

15. Pham, T.-T.-H.; Turner, S.; Trincsi, K. Applying a Systematic Review to Land Use Land Cover Change in Northern Upland Vietnam: The Missing Case of the Borderlands. Geogr. Res. 2015, 53, 419-435. [CrossRef]

16. Calatayud, A.; Palacin, R.; Mangan, J.; Jackson, E.; Ruiz-Rua, A. Understanding connectivity to international markets: A systematic review. Transp. Rev. 2016, 36, 713-736. [CrossRef]

17. Qin, H.; Liao, T.F. Labor out-migration and agricultural change in rural China: A systematic review and meta-analysis. J. Rural Stud. 2016, 47, 533-541. [CrossRef]

18. Krizaj, D.; Brodnik, A.; Bukovec, B. A Tool for Measurement of Innovation Newness and Adoption in Tourism Firms. Int. J. Tour. Res. 2014, 16, 113-125. [CrossRef]

19. Medina-Munoz, D.R.; Medina-Munoz, R.D.; Zuniga-Collazos, A. Tourism and Innovation in China and Spain: A Review of Innovation Research On Tourism. Tour. Econ. 2013, 19, 319-337. [CrossRef]

20. Simão, J.N.; Partidário, M.d.R. How Does Tourism Planning Contribute to Sustainable Development? Sustain. Dev. 2012, 20, 372-385. [CrossRef]

21. Solstrand, M.V. Marine angling tourism in Norway and Iceland: Finding balance in management policy for sustainability. Nat. Resour. Forum 2013, 37, 113-126. [CrossRef]

22. Bramwell, B. Governance, the state and sustainable tourism: A political economy approach. J. Sustain. Tour. 2011, 19, 459-477. [CrossRef]

23. Stumpf, T.S.; Swanger, N. Tourism involvement-conformance theory: A grounded theory concerning the latent consequences of sustainable tourism policy shifts. J. Sustain. Tour. 2015, 23, 618-637. [CrossRef]

24. Gössling, S.; Hall, C.M.; Ekström, F.; Engeset, A.B.; Aall, C. Transition management: A tool for implementing sustainable tourism scenarios? J. Sustain. Tour. 2012, 20, 899-916. [CrossRef]

25. Moyle, B.D.; McLennan, C.L.J.; Ruhanen, L.; Weiler, B. Tracking the concept of sustainability in Australian tourism policy and planning documents. J. Sustain. Tour. 2014, 22, 1037-1051. [CrossRef] 
26. Fernandez-Tabales, A.; Foronda-Robles, C.; Galindo-Perez-de-Azpillaga, L.; Garcia-Lopez, A. Developing a system of territorial governance indicators for tourism destinations. J. Sustain. Tour. 2017, 25, 1275-1305. [CrossRef]

27. Tanguay, G.A.; Rajaonson, J.; Therrien, M.C. Sustainable tourism indicators: Selection criteria for policy implementation and scientific recognition. J. Sustain. Tour. 2013, 21, 862-879. [CrossRef]

28. Saarinen, J. Traditions of sustainability in tourism studies. Ann. Tour. Res. 2006, 33, 1121-1140. [CrossRef]

29. Saarinen, J. Critical Sustainability: Setting the Limits to Growth and Responsibility in Tourism. Sustainability 2014, 6, 1-17. [CrossRef]

30. Fodness, D. The problematic nature of sustainable tourism: Some implications for planners and managers. Curr. Issues Tour. 2017, 20, 1671-1683. [CrossRef]

31. Vellecco, I.; Mancino, A. Sustainability and tourism development in three Italian destinations: stakeholders' opinions and behaviours. Serv. Ind. J. 2010, 30, 2201-2223. [CrossRef]

32. Butler, R.W. Sustainable tourism: A state-of-the-art review. Tour. Geogr. 1999, 1, 7-25. [CrossRef]

33. Xu, H.G.; Sofield, T. Sustainability in Chinese development tourism policies. Curr. Issues Tour. 2016, 19, 1337-1355. [CrossRef]

34. Collins, A. Tourism development and natural capital. Ann. Tour. Res. 1999, 26, 98-109. [CrossRef]

35. Mai, T.; Smith, C. Addressing the threats to tourism sustainability using systems thinking: A case study of Cat Ba Island, Vietnam. J. Sustain. Tour. 2015, 23, 1504-1528. [CrossRef]

36. Hall, C.M. Framing behavioural approaches to understanding and governing sustainable tourism consumption: Beyond neoliberalism, "nudging" and "green growth"? J. Sustain. Tour. 2013, 21, 1091-1109. [CrossRef]

37. Hall, C.M. Tourism and Politics: Policy, Power and Place; John Wiley \& Sons: Chichester, UK, 1994; Volume ix, $238 \mathrm{p}$.

38. Andersen, I.M.V.; Blichfeldt, B.S.; Liburd, J.J. Sustainability in coastal tourism development: An example from Denmark. Curr. Issues Tour. 2018, 21, 1329-1336. [CrossRef]

39. Scheyvens, R. The challenge of sustainable tourism development in the Maldives: Understanding the social and political dimensions of sustainability. Asia Pac. Viewp. 2011, 52, 148-164. [CrossRef]

40. Ong, L.T.J.; Smith, R.A. Perception and reality of managing sustainable coastal tourism in emerging destinations: The case of Sihanoukville, Cambodia. J. Sustain. Tour. 2014, 22, 256-278. [CrossRef]

41. Yüksel, A.; Yüksel, F.; Culha, O. Ministers' statements: A policy implementation instrument for sustainable tourism? J. Sustain. Tour. 2012, 20, 513-532. [CrossRef]

42. Bianchi, R.V. Tourism Restructuring and the Politics of Sustainability: A Critical View From the European Periphery (The Canary Islands). J. Sustain. Tour. 2004, 12, 495-529. [CrossRef]

43. Cao, X. Challenges and potential improvements in the policy and regulatory framework for sustainable tourism planning in China: The case of Shanxi Province. J. Sustain. Tour. 2015, 23, 455-476. [CrossRef]

44. Brohman, J. New directions in tourism for third world development. Ann. Tour. Res. 1996, 23, 48-70. [CrossRef]

45. Dodds, R. Sustainable Tourism and Policy Implementation: Lessons from the Case of Calviá, Spain. Curr. Issues Tour. 2007, 10, 296-322. [CrossRef]

46. Wong, E.P.Y.; Bauer, T.G.; Wong, K.K.F. A Critical Comparison of Tourism Policies of Hong Kong and Singapore - An Avenue to Mutual Learning. Int. J. Tour. Res. 2008, 10, 193-206. [CrossRef]

47. Wesley, A.; Pforr, C. The governance of coastal tourism: Unravelling the layers of complexity at Smiths Beach, Western Australia. J. Sustain. Tour. 2010, 18, 773-792. [CrossRef]

48. Hunter, C. Sustainable tourism as an adaptive paradigm. Ann. Tour. Res. 1997, 24, 850-867. [CrossRef]

49. Hunter, C.J. On the need to re-conceptualise sustainable tourism development. J. Sustain. Tour. 1995, 3, 155-165. [CrossRef]

50. Vernon, J.; Essex, S.; Pinder, D.; Curry, K. Collaborative policymaking. Ann. Tour. Res. 2005, 32, $325-345$. [CrossRef]

51. Timur, S.; Getz, D. Sustainable tourism development: How do destination stakeholders perceive sustainable urban tourism? Sustain. Dev. 2009, 17, 220-232. [CrossRef]

52. Moyle, C.-1.J.; Moyle, B.D.; Chai, A.; Hales, R.; Banhalmi-Zakar, Z.; Bec, A. Have Australia's tourism strategies incorporated climate change? J. Sustain. Tour. 2017, 26, 703-721. [CrossRef] 
53. Santos-Lacueva, R.; Clave, S.A.; Saladie, O. The Vulnerability of Coastal Tourism Destinations to Climate Change: The Usefulness of Policy Analysis. Sustainability 2017, 9, 2062. [CrossRef]

54. Dredge, D.; Jamal, T. Progress in tourism planning and policy: A post-structural perspective on knowledge production. Tour. Manag. 2015, 51, 285-297. [CrossRef]

55. Santos-Lacueva, R.; Gonzalez, M.V. Policy coherence between tourism and climate policies: The case of Spain and the Autonomous Community of Catalonia. J. Sustain. Tour. 2018, 26, 1708-1727. [CrossRef]

56. Weaver, D. Can sustainable tourism survive climate change? J. Sustain. Tour. 2011, 19, 5-15. [CrossRef]

57. Scott, D. Why sustainable tourism must address climate change. J. Sustain. Tour. 2010, 19, 17-34. [CrossRef]

58. Blancas, F.J.; Lozano-Oyola, M.; Gonzalez, M.; Guerrero, F.M.; Caballero, R. How to use sustainability indicators for tourism planning: The case of rural tourism in Andalusia (Spain). Sci. Total Environ. 2011, 412, 28-45. [CrossRef]

59. Choi, H.C.; Sirakaya, E. Sustainability indicators for managing community tourism. Tour. Manag. 2006, 27, 1274-1289. [CrossRef]

60. Ko, T.G. Development of a tourism sustainability assessment procedure: A conceptual approach. Tour. Manag. 2005, 26, 431-445. [CrossRef]

61. Miller, G. The development of indicators for sustainable tourism: Results of a Delphi survey of tourism researchers. Tour. Manag. 2001, 22, 351-362. [CrossRef]

62. Blancas, F.J.; Gonzalaz, M.; Lozano-Oyola, M.; Perez, F. The assessment of sustainable tourism: Application to Spanish coastal destinations. Ecol. Indic. 2010, 10, 484-492. [CrossRef]

63. Sharpley, R. Tourism and Sustainable Development: Exploring the Theoretical Divide. J. Sustain. Tour. 2000, 8,1-19. [CrossRef]

64. Buckley, R. Sustainable Tourism: Research and Reality. Ann. Tour. Res. 2012, 39, 528-546. [CrossRef]

65. Brendehaug, E.; Aall, C.; Dodds, R. Environmental policy integration as a strategy for sustainable tourism planning: Issues in implementation. J. Sustain. Tour. 2017, 25, 1257-1274. [CrossRef]

66. Dinica, V. Governance for sustainable tourism: A comparison of international and Dutch visions. J. Sustain. Tour. 2009, 17, 583-603. [CrossRef]

67. Baum, T. Sustainable human resource management as a driver in tourism policy and planning: A serious sin of omission? J. Sustain. Tour. 2018, 26, 873-889. [CrossRef] 